\section{STUDI KAPASITAS LENDUTAN, DAKTALITAS, DAN KEKAKUAN PADA BALOK BETON BERTULANG YANG DIPERKUAT GFRP-S DENGAN PERENDAMAN AIR LAUT SELAMA SATU TAHUN}

\author{
Asri Mulya Setiawan', Erniati Bachtiar ${ }^{2}$ \\ Universitas Fajar, Makassar ${ }^{1,2}$
}

Email: klanmulyasetiawan@gmail.com¹

\begin{abstract}
Abstrak. Penelitian ini bertujuan untuk menganalisis kapasitas lendutan, daktalitas dan kekakuan dari struktur balok beton bertulang yang diperkuat GFRP dengan perendaman air laut selama 1 tahun. Metode pengujian yang digunakan yaitu metode pembebanan monotonik yang menggunakan dua tumpuan sederhana diatas benda uji dan ditekan pada kecepatan ramp actuator konstan sebesar 0,05 $\mathrm{mm} / \mathrm{dtk}$ hingga balok beton mengalami kegagalan. Hasil pengujian menunjukkan bahwa $\mathrm{BF}_{0}$ lebih daktail bila dibandingkan dengan $\mathrm{BF}_{6}$ dan $\mathrm{BF}_{12}$. Hal ini dapat dilihat besar lendutan yang ada, dimana $\mathrm{BF}_{0}$ memiliki lendutan yang cenderung lebih besar dibandingkan dengan balok lainnya. Pada benda uji $\mathrm{BF}_{0}$ beban yang mampu ditahan lebih besar dibandingkan benda uji BN namun lendutan yang dihasilkan juga semakin besar.
\end{abstract}

Kata Kunci: Air Laut, Balok Beton, Daktail, Kekakuan, Lendutan, Perkuatan GFRP-S

\section{INDONESIAN JOURNAL OF FUNDAMENTAL SCIENCES (IJFS)}

\section{E-ISSN: 2621-6728 \\ P-ISSN: 2621-671X}

Submitted: April, $24^{\text {th }}, 2019$

Accepted : June, $13^{\text {th }}, 2019$

Abstract. This study aims to analyze the deflection capacity, ductality and stiffness of reinforced concrete beam structures reinforced by GFRP with sea water immersion for 1 year. The test method used is a monotonic loading method that uses two simple supports over the test object and is pressed at a constant ramp actuator speed of $0.05 \mathrm{~mm} / \mathrm{sec}$ until the concrete beam fails. The test results show that BFo is more ductile compared to BF6 and BF12. This can be seen the existing deflection, where BFo has a deflection that tends to be larger than the other beams. In BFo specimens, the load that is able to hold is greater than BN specimens, but the resulting deflection is also greater 


\section{PENDAHULUAN}

Perkembangan teknologi membawa pengaruh besar dalam dunia konstruksi, terutama dalam penelitian-penelitian tentang beton. Dalam dunia konstruksi beton memiliki peran yang sangat penting sebagai material utama yang banyak digunakan, hal ini tidak lepas dari kelebihan-kelebihan yang diberikan oleh beton itu sendiri, di antaranya tahan terhadap tekanan, kemudahan dalam pengerjaan, serta ekonomis dalam pembuatan dan perawatannya. Beton bertulang adalah struktur utama dalam dunia konstruksi. Beton bertulang terdiri dari campuran beton yang berfungsi untuk menahan gaya tekan yang diakibatkan oleh beban-beban yang diberikan dan baja tulangan yang berfungsi untuk menahan gaya tarik yang terjadi.

Balok beton merupakan elemen struktur yang bekerja untuk menahan lentur dan deformasi. Distribusi tegangan akibat beban lentur akan menyebabkan serat bagian atas balok tertekan dan serat bagian bawah balok tertarik. Beton yang lemah terhadap tarik menjadi penyebab utama terjadinya retak pada struktur beton bertulang dalam kondisi beban kerja. Retak yang terjadi pada struktur beton bertulang tentu akan mempengaruhi perilaku struktur tersebut.

Permasalahan-permasalahan struktur tersebut menyebabkan konstruksi yang telah berdiri (existing) biasanya perlu dibongkar ataupun direkonstruksi ulang sebagai dampak pencegahan terhadap kemungkinan runtuhnya konstruksi yang mungkin menimbulkan korban jiwa. Dengan berbagai kemajuan ilmu pengetahuan teknik maka lahirlah Glass Fiber Reinforced Polymer (GFRP) sebagai material solusi perkuatan dan perbaikan struktur yang telah banyak digunakan saat ini.

GFRP adalah bahan nonlogam sehingga tidak bersifat korosif yang selama ini digunakan untuk dua hal, yaitu untuk beton lama sebagai bahan perkuatan pada bagian konstruksi yang sudah mulai mengalami penurunan kinerja serta untuk beton baru dengan perkuatan proteksi dan reduksi penampang. GFRP ini telah digunakan secara meluas, tidak hanya terbatas pada konstruksi gedung namun juga dapat digunakan pada konstruksi lainnya. Konstruksi dalam bidang teknik sipil ada yang terekspos di darat seperti konstruksi gedung pada umumnya dan ada pula yang terekspos di lingkungan laut seperti konstruksi jetty pada dermaga dan konstruksi jembatan.

Pada umumnya, konstruksi yang terekspos di lingkungan laut akan mengalami penurunan kekuatan akibat adanya korosi yang terjadi pada tulangan. Oleh karena itu maka diperlukan penggunaan GFRP sebagai material perkuatan untuk diaplikasikan pada konstruksi tersebut karena selain berfungsi untuk meningkatkan kekuatan elemen struktur, GFRP ini juga memiliki ketahanan korosi yang baik sehingga sangat tepat untuk diaplikasikan pada elemen struktur yang terekspos lingkungan laut.

Lazimnya, GFRP diletakan pada bagian struktur yang mulai menunjukan penurunan kinerjanya, yaitu dengan cara menempelkan ataupun melilitkan GFRP pada bagian yang lemah, sehingga GFRP tersebut mampu menyokong struktur untuk tetap bertahan pada posisi yang diharapkan. Penelitian ini membahas tentang kapasitas lendutan, daktalitas dan kekakuan dari struktur balok beton bertulang yang diperkuat GFRP dengan perendaman air laut selama 1 tahun. 


\section{TINJAUAN PUSTAKA}

Penggunaan GFRP pada balok beton bertulang meningkatkan kapasitas beban bila dibandingkan dengan balok beton bertulang tanpa perkuatan GFRP. Peningkatan kapasitas bervariasi seiring dengan penambahan jumlah lapisan GFRP (Fikri Alam, 2010). Peningkatan kekuatan kapasitas momen ultimit balok dengan perkuatan GFRP terhadap balok normal antara lain adalah 1 lapis penuh (balok A1-GF) sebesar 59\%, 1 lapis penuh +2 lapis pada $1 / 3$ bentang tengah (balok A2-GF) sebesar $80 \%$, 3 lapis penuh (balok B1-GF) sebesar 112\%, 3 lapis penuh +2 lapis pada $1 / 3$ bentang tengah (balok B2-GF) sebesar 155\%. Hal ini menunjukkan bahwa terjadi peningkatan kapasitas beban seiring pertambahan jumlah lapisan GFRP. Ketika baja tulangan meleleh dan beton mengalami penurunan kekuatan, gaya tarik yang terjadi akibat pertambahan beban akan ditahan sepenuhnya oleh GFRP (Bukorsyom, 2011).

Lendutan yang terjadi pada balok GFRP-S yang direndam lebih kecil jika dibandingkan dengan lendutan balok GFRP-S yang tidak direndam. Penggunaan GFRP-S sangat baik diterapkan untuk meningkatkan kinerja suatu struktur, khususnya struktur yang terpengaruh lingkungan ekstrim seperti air laut. Dengan adanya penambahan GFRP-S, dapat melindungi struktur dari kerusakan akibat pengaruh air laut dan mengurangi degradasi kekuatan selama kurun waktu tertentu (Umar, 2014).

Kapasitas rekatan GFRP-S balok perendaman laut juga lebih kecil bila dibandingkan dengan balok perendaman kolam. Persentase selisih kapasitas rekatan antara balok perendaman kolam dengan balok perendaman laut sebesar $8.10 \%$, 14.34\% dan 15.38\% secara berurutan untuk lama perendaman 1 bulan, 3 bulan dan 6 bulan. Simulasi pemodelan dapat digunakan sebagai media perendaman air laut untuk mensimulasikan kondisi perendaman di laut sebenarnya dengan menggunakan suatu nilai faktor koreksi FK (Kwandou, 2014).

Terjadi peningkatan kapasitas beban pada benda uji balok beton bertulang dengan perkuatan GFRP-S yang direndam dengan air laut selama 12 bulan $\left(\mathrm{BF}_{12}\right)$ terhadap benda uji balok beton bertulang tanpa perkuatan GFRP-S ( $B N_{0}$ ) yaitu sebesar 54,292\% (Setiawan, 2015). Terjadi penurunan kapasitas lentur pada benda uji rendaman 1 bulan $\left(\mathrm{BF}_{1}\right), 3$ bulan $\left(\mathrm{BF}_{3}\right), 6$ bulan $\left(\mathrm{BF}_{6}\right)$ dan 12 bulan $\left(\mathrm{BF}_{12}\right)$ terhadap benda uji tanpa perendaman ( $\mathrm{BF}_{0}$ ) yaitu sebesar $2,74 \% ; 2,81 \% ; 3,90 \%$ dan $4,29 \%$. Penurunan kapasitas lentur ini disebabkan oleh melemahnya kapasitas rekatan GFRPS yang dipengaruhi oleh rendaman air laut (Sultan, 2015).

Beban maksimum rata-rata benda uji BNo (Balok normal tanpa perendaman) sebesar 26,74 kN; benda uji $\mathrm{BN}_{6}$ (Balok normal dengan perendaman selama 6 bulan) sebesar 26,37 kN atau terjadi penurunan kapasitas beban terhadap benda uji $\mathrm{BN}_{0}$ sebesar 1,383\%. Penurunan kapasitas benda uji $\mathrm{BN}_{6}$ ini setelah perendaman air laut selama 6 bulan. Beban maksimum rata-rata benda uji BFo (Balok GFRP tanpa perendaman), $\mathrm{BF}_{6}$ (Balok GFRP dengan perendaman selama 6 bulan) dan $\mathrm{BF}_{12}$ (Balok GFRP dengan perendaman selama 12 bulan) masing-masing 43,105 kN, 41,425 kN dan 41,258 kN. Serta terjadi penurunan beban balok GFRP-S yang direndam air laut terhadap balok GFRP-S tanpa perendaman $\left(\mathrm{BF}_{0}\right)$. Penurunan beban maksimum pada benda uji $\mathrm{BF}_{6}$ dan $\mathrm{BF}_{12}$ terhadap benda uji $\mathrm{BF}_{0}$. Persentase penurunan beban berturutturut adalah 3,898\% dan 4,285\% (Setiawan, 2018). 


\section{METODE PENELITIAN}

\section{A. Alat}

1. Alat ukur regangan baja tulangan (Strain Gauge tipe FLA-2-11)

2. Alat ukur regangan GFRP (Strain Gauge tipe FLA-2-11)

3. Alat ukur regangan beton (Strain Gauge tipe PL-60-11)

4. Alat ukur lendutan (LVDT)

5. Alat uji pembebanan (Actuator, Load Cell, Data Logger, Phi Gauge)

\section{B. Bahan}

1. Semen potland komposit

2. Agregat halus dan kasar (pasir dan batu pecah) berasal dari Bili-bili

3. Kawat dan besi tulangan produksi PT. Barawaja

4. Serat gelas GFRP-S tipe Tyfo SEH-51A produksi Fyfe.Co.LLC.

5. Bahan perekat tipe Tyfo S Epoxy produksi Fyfe.Co.LLC.

6. Air yang digunakan untuk campuran adalah air bersih.

\section{Metode Pengujian}

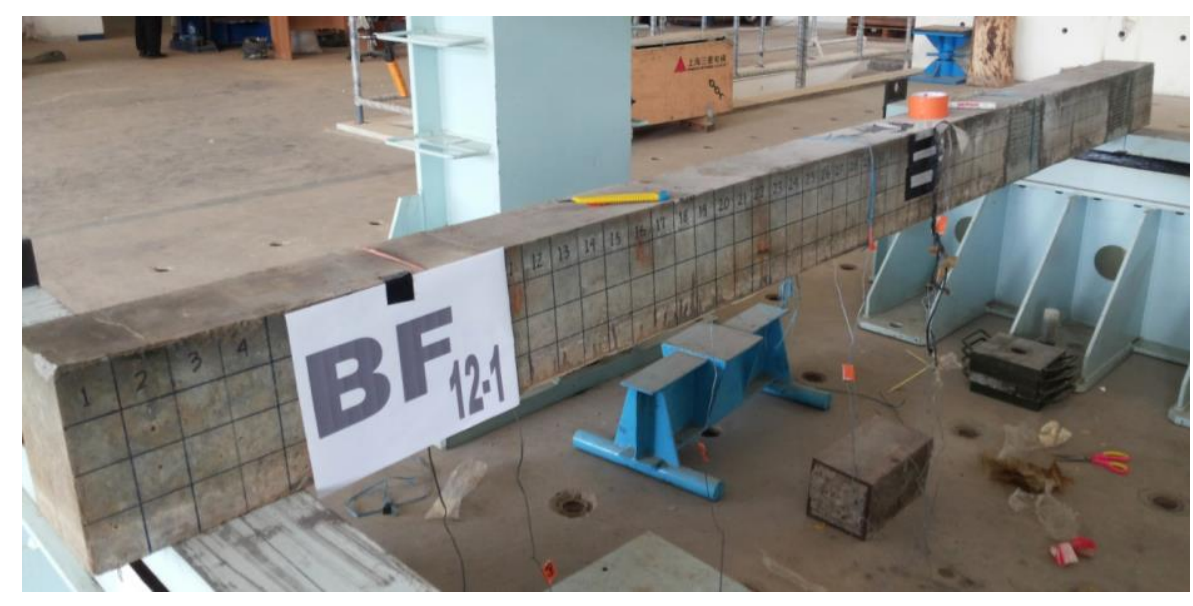

Gambar 1. Set Up Pengujian

Pengujian balok dilakukan dengan two poin load pada BN (balok normal) dan BF (balok GFRP), digunakan pembebanan yang bersifat monotonik, dengan kecepatan ramp actuator konstan sebesar $0,05 \mathrm{~mm} / \mathrm{dtk}$ sampai balok runtuh. Pengamatan terhadap balok uji dipantau secara visual, terutama terhadap perkembangan retak yang terjadi akibat bertambahnya beban, keadaan plastis, terhadap perilaku keruntuhan yang terjadi, serta pertambahan lendutan akibat bertambahnya beban. Pembebanan dilakukan hingga daerah tekan pada balok hancur dan telah mencapai beban maksimum.

Pengujian lentur dilaksanakan pada saat sampel balok yang telah terpasang GFRP-S berumur 1, 3, 6, dan 12 bulan yang telah berinteraksi dengan lingkungan laut. Pada saat pengujian lentur diadakan pengukuran lendutan dengan memasang LVDT pada bagian bawah balok serta pemeriksaan pola retakan yang terjadi dengan 
menggunakan phi gauge. Untuk regangan pada tulangan diagonal dan longitudinal juga pada permukaan beton, dipasang beberapa strain gauge pada posisi-posisi tertentu.

\section{Desain Benda Uji}

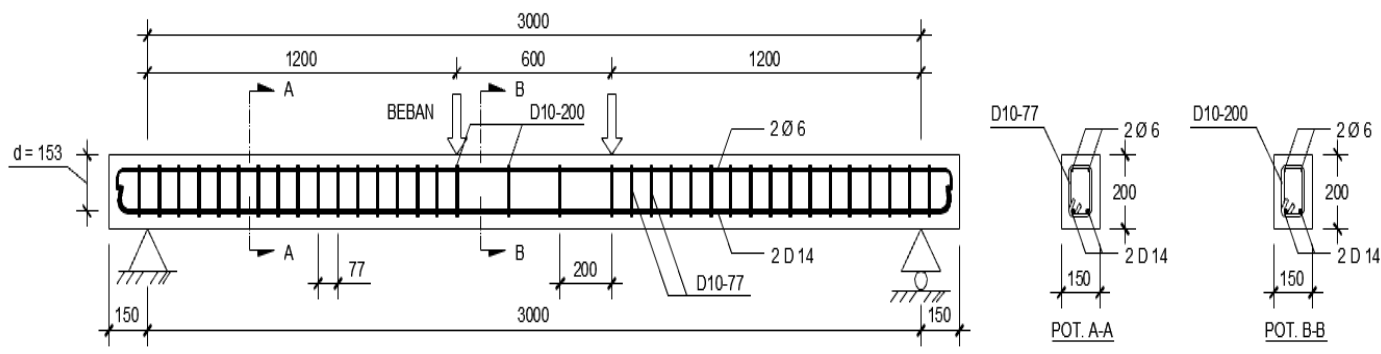

Gambar 2. Desain Benda Uji BN dan BF

Pengujian dilakukan dengan total 10 buah balok dengan dimensi $15 \mathrm{~cm} \times 20 \mathrm{~cm}$ x $330 \mathrm{~cm}$ yang direndam air laut pada kolam simulasi selama 1 tahun dengan mutu beton f'c 25 MPa. Perkuatan GFRP-S dilapisi pada daerah lentur balok beton dengan dimensi $15 \mathrm{~cm} \times 280 \mathrm{~cm}$. Adapun data yang diamati selama pengujian meliputi beban retak, beban plastis, dan beban ultimit, serta besaran lendutan. Untuk pemasangan GFRP-S digunakan metode Wet Lay-up . Bahan perekat yang digunakan dalam penelitian ini juga merupakan produk dari Fyfe Co dengan nama Tyfo S komponen A dan komponen B. Proses pemasangan GFRP-S terdiri atas lima tahap yaitu tahap pertama adalah penghalusan permukaan beton. Tahap kedua adalah pemotongan GFRP-S sesuai dengan ukuran dimana dalam hal ini digunakan GFRP-S sepanjang 3 meter sebanyak 2 lapis. Tahap ketiga adalah pencampuran epoxy yang dalam hal ini digunakan Tyfo $\mathrm{S}$ komponen $\mathrm{A}$ dan komponen B. Tahap keempat adalah pencampuran epoxy dan GFRP-S. Tahap kelima adalah penempelan GFRP-S pada benda uji menggunakan metode wet-layup.

\section{HASIL DAN PEMBAHASAN}

Hubungan beban dan lendutan ini diperoleh dari hasil pengujian menggunakan LVDT. Idelisasi hubungan dan lendutan yang dicari :

a. Tahap pertama sebelum terjadi retak (precracking).

b. Tahap kedua setelah terjadi retak (post cracking).

c. Tahap ketiga, dimana tulangan tarik sudah leleh tetapi balok masih mampu menahan beban, atau dengan kata lain balok sudah mengalami keruntuhan (post serviceability cracking).

Untuk mengevaluasi beban ultimit benda uji maka dibuat kurva bebanlendutan yang datanya diambil pada saat pengujian. 
Tabel 1. Hubungan beban lendutan pada semua benda uji

\begin{tabular}{|c|c|c|c|c|c|c|c|c|}
\hline \multirow{3}{*}{ Balok uji } & \multicolumn{8}{|c|}{ Hasil pengujian } \\
\hline & $P_{\text {crack }}$ & Lendutan & Pleleh & Lendutan & Pultimit & Lendutan & $\Delta \mathrm{u} / \Delta \mathrm{y}$ & $\mathrm{P} / \Delta$ \\
\hline & $(\mathrm{kN})$ & $(\mathrm{mm})$ & $(\mathrm{kN})$ & $(\mathrm{mm})$ & $(\mathrm{kN})$ & $(\mathrm{mm})$ & & \\
\hline $\mathrm{BN}_{0-1}$ & 5,07 & 2,66 & 22,97 & 15,11 & 27,04 & 34,59 & & \\
\hline $\mathrm{BN}_{0-2}$ & 5,07 & 2,66 & 22,83 & 15,87 & 26,44 & 43,25 & & \\
\hline $\mathrm{BN}_{0}$ & 5,07 & 2,66 & 22,90 & 15,49 & 26,74 & 38,92 & 2,513 & 0.687 \\
\hline $\mathrm{BN}_{6}$ & 5,13 & 1,95 & 22,16 & 22,62 & 26,37 & 28,19 & 1,246 & 0.935 \\
\hline $\mathrm{BF}_{0-1}$ & 10,08 & 3,95 & 32,31 & 18,04 & 43,26 & 39,34 & & \\
\hline $\mathrm{BF}_{\mathrm{O}-2}$ & 8,08 & 3,44 & 31,24 & 18,79 & 42,33 & 37,24 & & \\
\hline $\mathrm{BF}_{0-3}$ & 8,00 & 4,74 & 33,65 & 23,72 & 43,73 & 44,56 & & \\
\hline $\mathrm{BF}_{0}$ & 8,72 & 4,04 & 32,40 & 20,18 & 43,10 & 40,38 & 2,001 & 1.067 \\
\hline $\mathrm{BF}_{6-1}$ & 8,14 & 2,27 & 39,12 & 30,94 & 41,93 & 34,94 & & \\
\hline $\mathrm{BF}_{6-2}$ & 10,15 & 2,76 & 36,45 & 23,85 & 40,92 & 34,39 & & \\
\hline $\mathrm{BF}_{6}$ & 9,15 & 2,52 & 37,79 & 27,39 & 41,42 & 34,66 & 1,265 & 1.195 \\
\hline $\mathrm{BF} 12-1$ & 11,28 & 2,08 & 26,17 & 14,75 & 40,26 & 39,76 & & \\
\hline BF12-2 & 11,22 & 2,02 & 36,58 & 17,31 & 42,06 & 21,11 & & \\
\hline BF12 & 11,25 & 2,05 & 31,38 & 16,03 & 41,16 & 30,44 & 1,899 & 1.352 \\
\hline
\end{tabular}

Tabel 1 memperlihatkan perbedaan kekuatan antara benda uji BF. Dimana benda uji $\mathrm{BF}_{6}$ dan $\mathrm{BF}_{12}$, dengan $\mathrm{BF}_{0}$ tidak terlalu besar, namun sifat $\mathrm{BF}_{0}$ lebih daktail bila dibandingkan dengan $\mathrm{BF}_{6}$ dan $\mathrm{BF}_{12}$. Hal ini dapat dilihat besar lendutan yang ada, dimana $\mathrm{BF}_{0}$ memiliki lendutan yang cenderung lebih besar dibandingkan dengan balok lainnya. Hubungan beban dan lendutan antara BN dengan BF, menunjukkan bahwa penambahan lapisan GFRP-S mampu meningkatkan kapasitas benda uji BF. Namun sifat dari balok akan semakin getas, sehingga keruntuhan balok akan terjadi secara tiba-tiba tanpa peringatan.

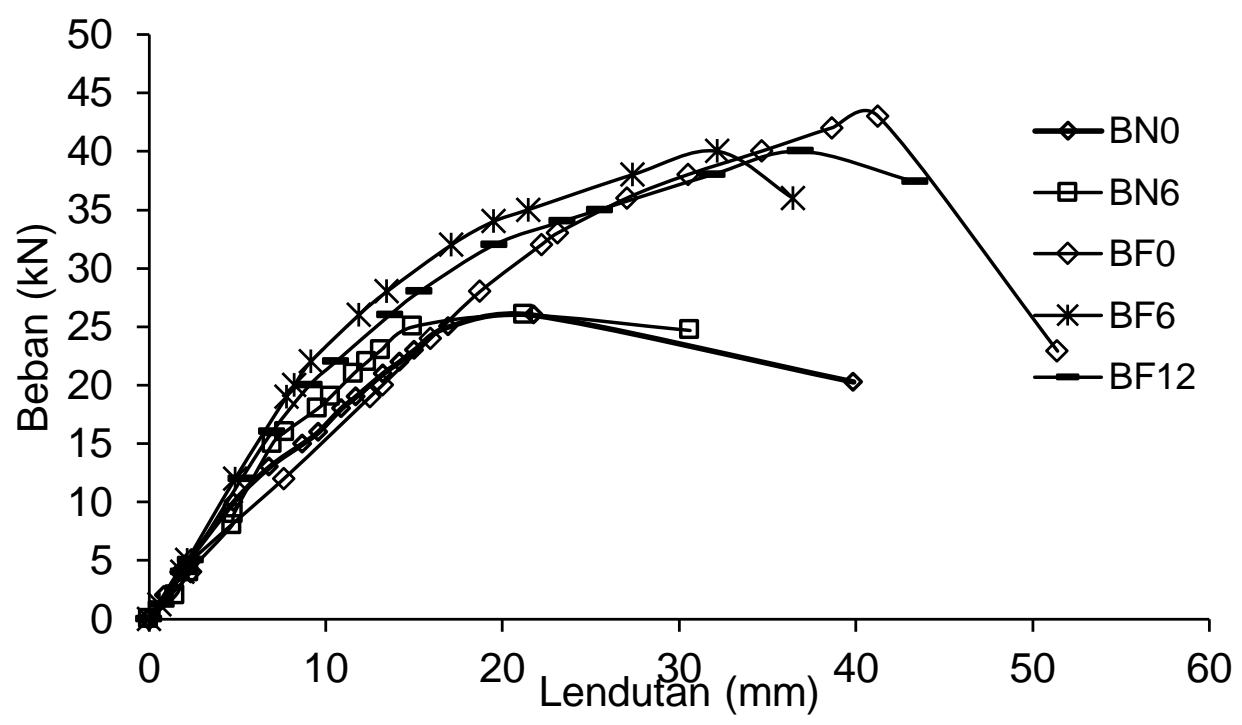

Gambar 3. Hubungan beban - lendutan seluruh benda uji 
Grafik hubungan beban dan lendutan untuk seluruh sampel pada Gambar 3 menunjukkan bahwa penambahan lapisan GFRP-S mampu meningkatkan kapasitas beban ultimit benda uji. Pada benda uji $\mathrm{BF}_{\mathrm{o}}$. beban yang mampu ditahan lebih besar dibandingkan benda uji BN namun lendutan yang dihasilkan juga semakin besar. untuk balok normal yang direndam selama 6 bulan $\left(\mathrm{BN}_{6}\right)$, beban dan lendutan yang dihasilkan lebih besar dibandingkan dengan balok normal yang tidak direndam. Sementara itu pada benda uji $\mathrm{BF}_{6}$ dan $\mathrm{BF}_{12}$ beban yang mampu ditahan lebih kecil dan lendutan yang dihasilkan juga lebih kecil dibandingkan benda uji $\mathrm{BF}_{0}$. Gambar 4 menunjukkan benda uji pada beban yang sama, pada beban $20 \mathrm{kN}$ terlihat bahwa lendutan pada benda uji BN cenderung lebih besar terhadap BF, pada beban $40 \mathrm{kN}$ lendutan $\mathrm{BF}_{12}$ cenderung lebih besar dari $\mathrm{BF}_{6}$, dan $\mathrm{BF}_{0}$.

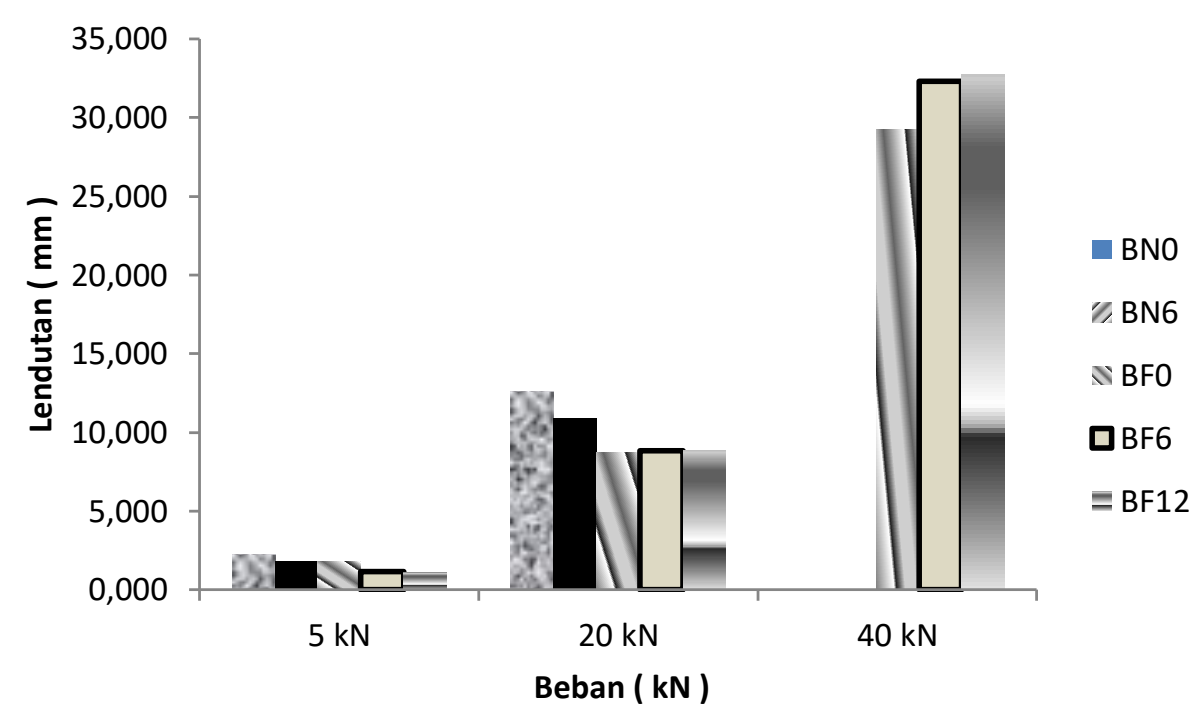

Gambar 4. Histogram lendutan terhadap variasi beban setiap umur pengaruh rendaman air laut

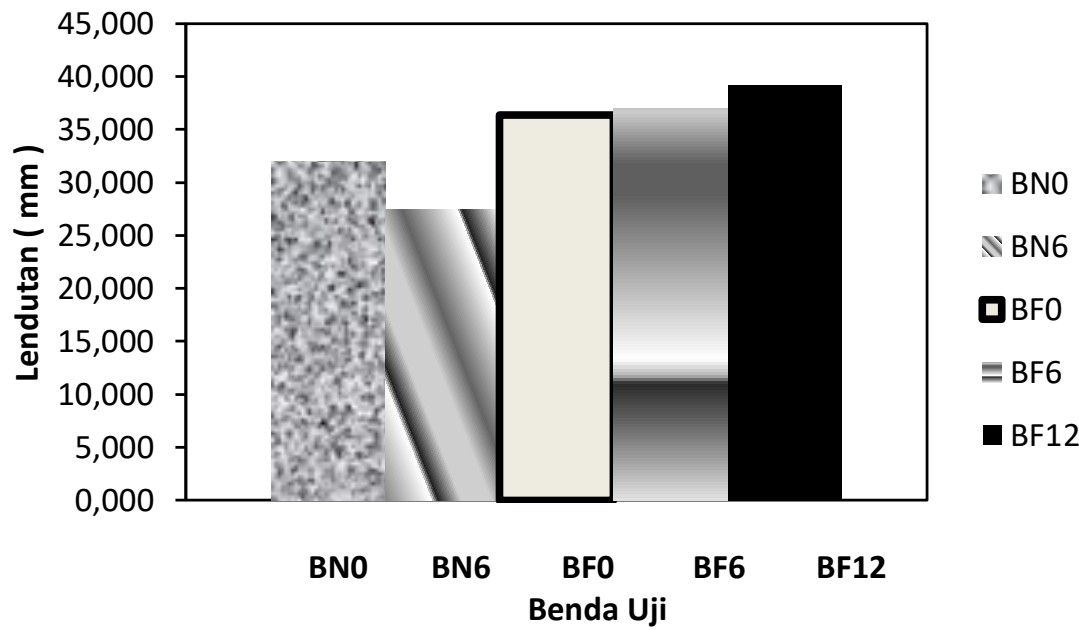

Gambar 5. Histogram lendutan maksimum 
Gambar 5 menunjukkan histogram lendutan maksimum benda uji. Beban maksimum benda uji yang dipengaruhi rendaman air laut kecenderungan lendutan rata-rata semakin besar. Perbandingan antara beban maksimum dan lendutan yang dihasilkan benda uji yang diperkuat GFRP-S cenderung sama . Dari Gambar 4 dan Gambar 5 diperoleh bahwa lendutan yang dihasilkan balok yang direndam air laut lebih kecil dari lendutan balok yang tidak direndam. Hal ini menunjukan bahwa sifat kekakuan dari balok yang tidak direndam lebih besar dibandingkan dengan balok yang direndam. Sesuai dengan teorinya bahwa semakin daktail beton maka semakin tidak kaku beton tersebut. Begitupula sebaliknya, semakin kaku beton maka semakin tidak daktail beton itu.

\section{Daktalitas}

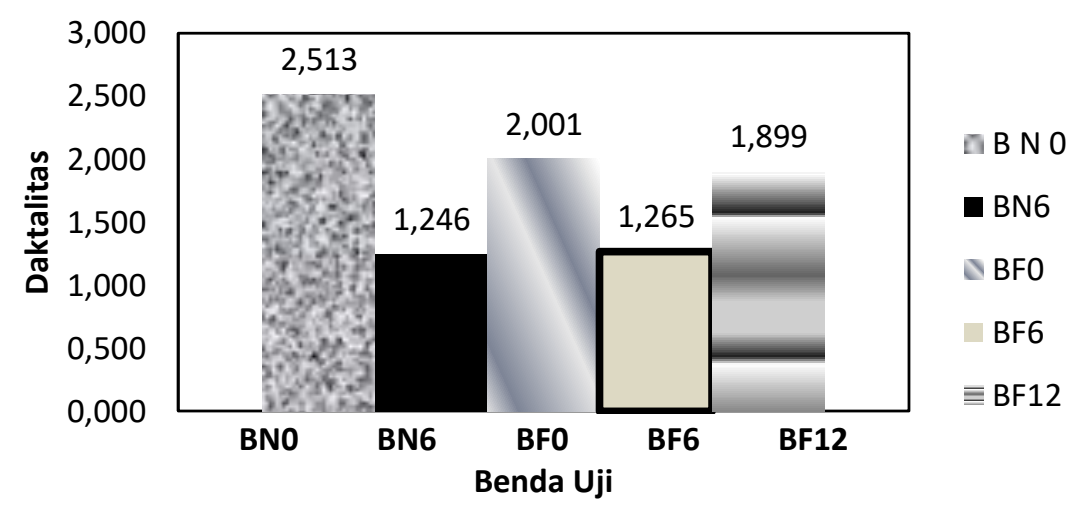

Gambar 6. Tingkat daktalitas seluruh benda uji

Dari Gambar 6 menunjukkan bahwa benda uji BFo lebih daktail dibandingkan benda uji BF6 dan BF12. Ini menunjukkan bahwa tingkat daktalitas benda uji yang direndam air laut lebih kecil jika dibandingkan dengan benda uji tanpa perendaman. Begitu pula dengan benda uji BNo memiliki nilai daktalitas yang lebih tinggi dibandingkan BN6.

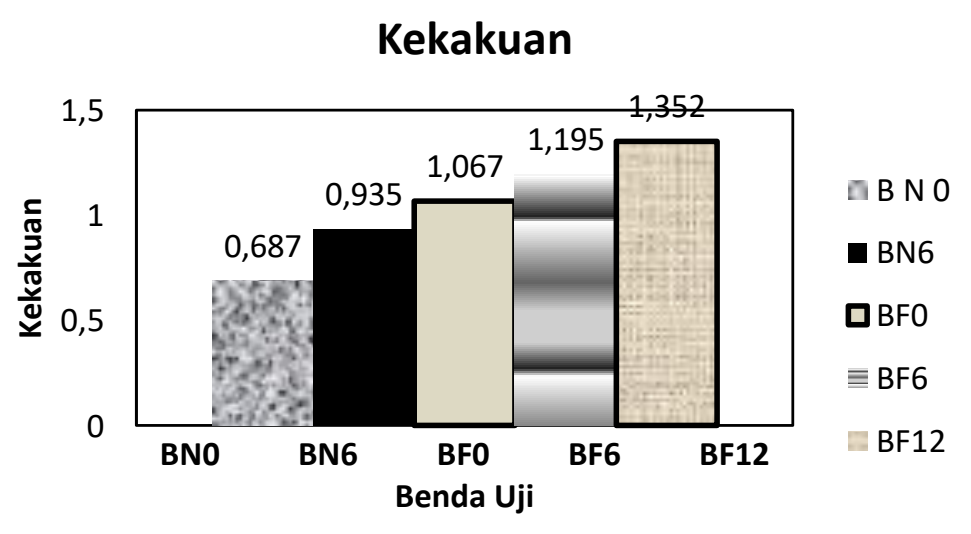

Gambar 7. Tingkat kekakuan seluruh benda uji 
Pada Gambar 7 menunjukkan bahwa BF12 dan BF6 lebih getas (kaku) dibandingkan BFo. Begitupula dengan BN6 yang memiliki nilai kekakuan yang lebih tinggi dibandingkan BNo. Hal ini menunjukkan bahwa sifat kekakuan balok yang direndam lebih besar jika dibandingkan balok tanpa perendaman. Selain itu menunjukkan bahwa penambahan lapisan GFRP-S mampu meningkatkan kapasitas benda uji BF. Namun sifat dari balok akan semakin getas, sehingga keruntuhan balok akan terjadi secara tiba-tiba tanpa peringatan.

\section{KESIMPULAN}

Berdasarkan hasil dan pembahasan dari pengaruh air laut terhadap kapasitas beban balok beton dengan perkuatan GFRP-S yang direndam selama satu tahun dapat ditarik kesimpulan, bahwa:

1. $\mathrm{BF}_{0}$ lebih daktail bila dibandingkan dengan $\mathrm{BF}_{6}$ dan $\mathrm{BF}_{12}$. Hal ini dapat dilihat besar lendutan yang ada, dimana $\mathrm{BF}_{0}$ memiliki lendutan yang cenderung lebih besar dibandingkan dengan balok lainnya. Hubungan beban dan lendutan antara BN dengan BF, menunjukkan bahwa penambahan lapisan GFRP-S mampu meningkatkan kapasitas benda uji BF. Namun sifat dari balok akan semakin getas, sehingga keruntuhan balok akan terjadi secara tiba-tiba tanpa peringatan.

2. Pada benda uji $\mathrm{BF}_{\mathrm{o}}$ beban yang mampu ditahan lebih besar dibandingkan benda uji BN namun lendutan yang dihasilkan juga semakin besar. untuk balok normal yang direndam selama 6 bulan $\left(\mathrm{BN}_{6}\right)$, beban dan lendutan yang dihasilkan lebih besar dibandingkan dengan balok normal yang tidak direndam. Sementara itu pada benda uji $\mathrm{BF}_{6}$ dan $\mathrm{BF}_{12}$ beban yang mampu ditahan lebih kecil dan lendutan yang dihasilkan juga lebih kecil dibandingkan benda uji $\mathrm{BF}_{0}$. Ini menunjukkan bahwa penambahan lapisan GFRP-S mampu meningkatkan kapasitas beban ultimit benda uji.

3. Lendutan yang dihasilkan balok yang direndam air laut lebih kecil dari lendutan balok yang tidak direndam. Hal ini menunjukan bahwa sifat kekakuan dari balok yang tidak direndam lebih besar dibandingkan dengan balok yang direndam, Sesuai dengan teorinya bahwa semakin daktail beton maka semakin tidak kaku beton tersebut. Begitupula sebaliknya, semakin kaku beton maka semakin tidak daktail beton itu.

4. Benda uji BFo lebih daktail dibandingkan benda uji BF6 dan BF12. Ini menunjukkan bahwa tingkat daktalitas benda uji yang direndam air laut lebih kecil jika dibandingkan dengan benda uji tanpa perendaman. Begitu pula dengan benda uji BNo memiliki nilai daktalitas yang lebih tinggi dibandingkan BN6.

5. BF12 dan BF6 lebih getas (kaku) dibandingkan BFo. Begitupula dengan BN6 yang memiliki nilai kekakuan yang lebih tinggi dibandingkan BNo. Hal ini menunjukkan bahwa sifat kekakuan balok yang direndam lebih besar jika dibandingkan balok tanpa perendaman. Selain itu menunjukkan bahwa penambahan lapisan GFRP-S mampu meningkatkan kapasitas benda uji BF. Namun sifat dari balok akan semakin getas, sehingga keruntuhan balok akan terjadi secara tiba-tiba tanpa peringatan. 


\section{DAFTAR PUSTAKA}

Alam Fikri. (2010). Perkuatan Lentur Balok Beton Bertulang dengan Glass Fiber Reinforced Polymer (GFRP-S). Seminar dan Pameran HAKI 2010: 1-12.

Bukorsyom, Febby. (2011). Studi Perkuatan Lentur Balok Beton Bertulang Pasca Kerusakan Dengan Menggunakan Glass Fiber Reinforced Polimer Sheet, Tesis, Program Magister Universitas Hasanuddin, Makassar.

Kwandou R. S. (2014). Simulasi Laboratorium Pengaruh Rendaman Air Laut Terhadap Kapasitas Rekatan GFRP-S Pada Balok Beton Bertulang.

Setiawan A. M. (2015). Pengaruh Air Laut Terhadap Kuat Lentur Balok Beton Bertulang Dengan Perkuatan GFRP-S Yang Direndam Selama Satu Tahun. Tesis, Program Magister Universitas Hasanuddin, Makassar.

Setiawan A. M. (2018). Pengaruh Air Laut Terhadap Kapasitas Beban Pada Balok Beton Bertulang Yang Diperkuat Gfrp-S Dengan Perendaman Selama Satu Tahun. Indonesian Journal of Fundamental Sciences, Volume 4 No.2, Desember 2018:136-146.

Sultan M. A. (2015). Pengaruh Air Laut Terhadap Karakteristik Balok Beton Bertulang Diperkuat Dengan GFRP-S.

Umar Irma, (2014). Studi Pengaruh Rendaman Air Laut Terhadap Kapasitas Balok Lentur Balok Beton Bertulang Yang Diperkuat GFRP-S. Tesis, Program Magister Universitas Hasanuddin, Makassar. 